\title{
Pengaruh Bisnis Social Media Instagram terhadap Aktivitas Pengguna Instagram di Kalangan Mahasiswa Ilmu Komunikasi
}

\author{
Riastri Novianita \\ jl. Kayu Jati V No.2, RW.5, Rawamangun, Kec. Pulo Gadung, Kota Jakarta Timur, Daerah \\ Khusus Ibukota Jakarta 13220 \\ Email: riastri.rsv@bsi ac.id
}

\begin{abstract}
Artikel info
Artikel history:

Diterima 14 Mei 2021

Diterima dalam bentuk revisi 07 Juni 2021

Diterima dalam bentuk revisi 18 Juni 2021

Keywords:

digital; marketing; online.

Abstract:

Today, people are spending more and more money online, which has shifted business emphasis to digital digital revenue sources. The growth of the digital economy has made people more acquainted with digital products and services, which has encouraged companies to seek new competitive advantages in the digital space. This study aims to provide a complete and in-depth description of the use of social media as a product marketing media in an effort to support the selling power of the product. The data obtained will be analyzed qualitatively, namely the analysis carried out by understanding and assembling the data that has been collected and compiled systematically, then conclusions are drawn. Based on the results of my interview with Bagas as a student at Bina Sara Informatics University and representatives from students who have small businesses. In conclusion, information technology has an important role in marketing MSME products in already utilizing it with product introduction on their site. However, this marketing model is only done on the site. There is no marketing optimization through the use of social media.
\end{abstract}

Kata Kunci:

digital; marketing; online.

\section{Abstrak:}

Saat ini, orang-orang membelanjakan lebih banyak uang secara online, yang telah mengalihkan penekanan bisnis ke sumber pendapatan digital digital. Pertumbuhan ekonomi digital membuat masyarakat semakin mengenal produk dan layanan digital, yang mendorong perusahaan mencari keunggulan kompetitif baru di ruang digital. Penelitian ini bertujuan memberikan uraian secara lengkap dan mendalam mengenai pemanfaatan media sosial sebagai media pemasaran produk dalam upaya mendukung daya jual produk tersebut. Data yang diperoleh akan dianalisis secara kualitatif yaitu analisis yang dilakukan dengan memahami dan merangkai data yang telah dikumpulkan dan disusun secara sistematis, kemudian ditarik kesimpulan. Berdasarkan hasil wawancara peneliti dengan Bagas selaku Mahasiswa di Universitas Bina Sara Informatika dan perwakilan dari pihak mahasiswa yang memiliki usaha kecil kecilan. Kesimpulanya Teknologi informasi memiliki peranan penting dalam memasarkan produk UMKM sudah memanfaatkan hal dengan pengenalan produk di situs mereka. Namun, model pemasaran ini baru dilakukan di situs saja. Belum ada optimalisasi pemasaran melalui penggunaan media sosial.

Coresponden author: Riastri Novianita

Email: riastri.rsv@bsi ac.id artikel dengan akses terbuka dibawah lisensi

CC BY SA 2021 


\section{Pendahuluan}

Pertumbuhan Ekonomi Digital Saat ini, orang-orang membelanjakan lebih banyak uang secara online, yang telah mengalihkan penekanan bisnis ke sumber pendapatan digital dan saluran digital. Pertumbuhan ekonomi digital membuat masyarakat semakin mengenal produk dan layanan digital, yang mendorong perusahaan mencari keunggulan kompetitif baru di ruang digital.

Tetapi bisnis digital telah berkembang menjadi lebih dari sekedar menjual secara online; menurut Accenture, "Bisnis digital menciptakan keunggulan kompetitif berdasarkan kombinasi unik dari sumber daya digital dan fisik. Mereka melakukan hal-hal yang tidak dapat dilakukan orang lain dandengan cara yang membangun keunggulan komparatif." (De Fritz, 2020).

Elemen Umum Bisnis Digital Ada beberapa pandangan tentang definisi pasti bisnis digital dari para pakar industri. Gartner mengatakan bahwa bisnis digital adalah penciptaan rantai nilai baru dan peluang bisnis yang tidak dapat ditawarkan oleh bisnis tradisional (Fajrillah et al., 2020). (Brown, Sikes, \& Willmott, 2013) menekankan bahwa "digital harus dilihat lebih sedikit sebagai sesuatu dan lebih banyak cara melakukan sesuatu."

Sebagian besar bisnis digital sesuai dengan satu atau kedua poin ini; mereka berfokus pada menciptakan nilai di batas baru untuk bisnis inti mereka, atau mereka menggunakan teknologi digital untuk mendorong pertumbuhan, pendapatan, dan kinerja dengan cara yang tidak mungkin dilakukan dengan model tradisional.

Mungkin bermanfaat bagi perusahaan untuk meninjau elemen umum bisnis digital dan membandingkannya dengan model bisnis mereka sendiri. Ini adalah beberapa tren yang membedakan digital dari proses tradisional.

Gunakan teknologi yang ada untuk memotong biaya, mengumpulkan data, dan memberikan pengalaman pelanggan yang lebih baik. Bisnis digital berfokus pada keunggulan kompetitif yang diperoleh teknologi, baik itu mengurangi biaya overhead atau memberikan nilai baru kepada pelanggan mereka (Aisyah, 2007).

Rangkul konsep transformasi digital dan perubahan budaya yang dibutuhkan. Penerapan dan pengelolaan layanan digital dapat memerlukan restrukturisasi organisasi, terutama dengan terciptanya peran baru dan IT diberikan masukan yang lebih besar ke dalam keputusan strategis. Jelajahi model bisnis baru yang menempatkan pengalaman pelanggan di pusat strategi digital. Orang sering kali bersedia membelanjakan lebih banyak untuk pengalaman pelanggan yang luar biasa, menjadikannya pembeda utama dalam ekonomi digital. Model bisnis yang sejalan dengan fokus utama pada kepuasan pelanggan ini pada akhirnya akan berpusat pada layanan digital, karena digital semakin menjadi pengalaman yang disukai orang.

Bisnis digital mengubah cara organisasi menggunakan dan berpikir tentang teknologi, memindahkan teknologi dari pemain pendukung menjadi pemain terdepan dalam inovasi, pendapatan, dan pertumbuhan pasar (Sisca et al., 2021). Bisnis digital lebih berfokus pada bagaimana teknologi memungkinkan perusahaan menciptakan nilai dan pengalaman baru yang membedakan perusahaan dan memberi mereka keunggulan kompetitif atas rekan-rekan mereka.

Jenis-jenis model Bisnis Digital Perkembangan digital memunculkan banyaknya model bisnis baru yang semakin beragam dan adaptif. Dengan berbagai teknologi seperti 
pembayaran online, model langganan, dan lain sebagainya membuat bisnis juga bisa mengeksplorasi peluang-peluang lain di dunia digital. Bisnis bisa mendapatkan keuntungan dengan lebih modern menggunakan satu atau berbagai macam model bisnis digital seperti layaknya startup.

Model bisnis yang bagus adalah salah satu faktor utama dalam keberhasilan bisnis. Model-model ini seringkali muncul dari adaptais bisnis lama yang adaptif di era digital. Terdapat banyak jenis model bisnis dalam dunia digital, namun secara sederhana kita akan mengklasifikasikan hal tersebut dalam 9 model, yaitu:

Brokerage/Marketplace Model bisnis ini pada intinya menghubungkan penjual dan pembeli pada satu tempat. Brokerage atau lebih modern disebut marketplace akan mendapatkan keuntungan dari biaya layanan penggunaan platform, komisi penjualan, maupun jasa iklan untuk penjual. Model bisnis ini mengarahkan upaya bisnis untuk mengumpulkan sebanyak banyaknya penjual dan pembeli. Contoh yang paling umum di Indonesia seperti: Tokopedia, Shopee, Bukalapak, dan lain sebagainya

Advertising Model bisnis ini menghubungkan para pemasang iklan dengan pemilik media. Dalam digital, seringkali pemilik media juga mempunyai model bisnis advertising untuk menyediakan iklan langsung ke platformnya. Model bisnis ini mendapatkan keuntungan dari persentase komisi menjual iklan, atau biaya iklan jika memiliki platform media. Model ini mengandalkan banyaknya pengguna yang bisa diberi iklan oleh para pemasang iklan. Contoh perusahaan yang menggunakan model ini adalah Google dengan Google Ads, Facebook dan Instagram dengan Facebook Ads, serta beberapa marketplace seperti Shopee dengan Shopee Iklanku Infomediary.

Model bisnis ini menghubungkan konsumen dengan kurasi informasi yang bersifat spesifik dan bernilai. Model bisnis ini mendapatkan keuntungan dari biaya langganan atau biaya akses. Model ini mengandalkan kualitas dari kurasi informasi yang disediakan, semakin berkualitas atau bermanfaat maka semakin mahal harga yang ditawarkan. Contoh perusahaan yang memakai model bisnis ini adalah Kompas dengan kompas.id dan Bloomberg dengan Bloomberg Terminal /Merchant.

Model bisnis ini sama seperti model bisnis yang sudah ada sebelum era digital, namun perbedaannya terletak pada pemanfaatan digital sebagai saluran distribusi dan pemasaran. Model bisnis ini mendapatkan keuntungan dari penjualan produk yang dihasilkan.

Manufacturer Model bisnis ini sama dengan sebelumnya, memanfaatkan kekuatan digital untuk membuat proses bisnis lebih efisien dan efektif. Model bisnis ini mendapatkan keuntungan dari penjualan produk yang dibuat. Manufacturer dapat menjual produk langsung ke konsumen maupun ke jaringan distributor yang dimiliki.

Affiliate Model bisnis ini menawarkan produk yang dimiliki oleh perusebagai ganti untuk menggunakan layanan yang ditawarkan. Semakin anyak pengguna yang dimiliki maka semakin besar penghasilan yang didapatkan. Contoh perusahaan yang menjalankan model bisnis iniadalah Netflix, Spotify, dan lainnya.

Utility/On-demand Model bisnis ini membebankan biaya sesuai layanan yang digunakan. Kita banyak melihat model bisnis ini semakin efektif dengan banyaknya tawaran layanan yang ditawarkan. Contoh perusahaan yang menjalankan model bisnis ini adalah Gojek dan Grab. 
Pada praktiknya, seringkali model bisnis digital ini dipakai secara bersamaan untuk memperkuat ekosistem digital yang dimiliki. Seperti misalnya community, infomediary, dan subscription banyak sekali dipakai menjadi dasar model bisnis perusahaanmedia modern. Selain itu, model bisnis ini juga menjadi sangat adaptif dengan perkembangan agar konsumen lebih nyaman.

\section{Metode Penelitian}

Metodologi pada penelitian ini yaitu metode studi kasus. Menurut (Kriyantono, 2006), metode studi kasus yaitu metode riset yang menggunakan berbagai sumber data yang bisa digunakan untuk meneliti, menguraikan dan menjelaskan secara komprehensif berbagai aspek individu, kelompok, suatu program, organisasi atau peristiwa secara sistematis.

Studi kasus adalah studi kasus adalah metode riset yang menggunakan berbagai sumber data sebanyak mungkin data) yang bisa digunakan untuk meneliti, menguraikan, dan menjelaskan secara komprehensif berbagai aspek individu, kelompok, suatu program, organisasi atau peristiwa secara sistematis. Penelaahaan berbagai sumber data ini membutuhkan berbagai macam instrumen pengumpulan data. Karena itu, periset dapat menggunakan wawancara mendalam, observasi partisipan, dokumentasi-dokumentasi, kuesioner (hasil survei), rekaman, bukti-bukti fisik lainnya (Kriyantono, 2006). Sementara itu, (Yin, 2006) memberi batas nmengenai studi kasus sebagai riset yang menyelidiki fenomena di dalam konteks kehidupan nyata, bilamana batas-batas antara fenomena dan konteks tak tampak dengan jelas, dan di mana multisumber dimanfaatkan. Penggunaan metode studi kasus pada pembahasan jurnal ini adalah studi kasus dengan fokus pada pemanfaatan media sosial sebagai media pemasaran produk dan potensi yang digunakan oleh UMKM bagi salah satu mahasiswa Universitas Bina Sarana Informatika.

Penggunaan studi kasus sebagai metode penelitian dipilih karena penelitian ini bertujuan memberikan uraian secara lengkap dan mendalam mengenai pemanfaatan media sosial sebagai media pemasaran produk dalam upaya mendukung daya jual produk tersebut. Data yang diperoleh akan dianalisis secara kualitatif yaitu analisis yang dilakukan dengan memahami dan merangkai data yang telah dikumpulkan dan disusun secara sistematis, kemudian ditarik kesimpulan. (Pawito, 2008) mengemukakan bahwa dalam penelitian kualitatif, kesimpulan yang dihasilkan pada umumnya tidak dimaksudkan sebagai generalisasi, tetapi sebagai gambaran interpretatif tentang realitas atau gejala yang diteliti secara holistik dalam setting tertentu. Di sini, arti bahwa temuan apapun yang dihasilkan pada dasarnya bersifat terbatas pada kasus yang diamati. Oleh karena itu, prinsip berfikir data yang diperoleh akan dianalisis secara kualitatif yaitu analisis yang dilakukan dengan memahami dan merangkai data yang telah dikumpulkan dan disusun secara sistematis, kemudian ditarik kesimpulan. (Pawito, 2008) mengemukakan bahwa dalam penelitian kualitatif, kesimpulan yang dihasilkan pada umumnya tidak dimaksudkan sebagai generalisasi, tetapi sebagai interpretatif tentang realitas atau gejala yang diteliti secara holistik dalam setting tertentu. Di siarti bahwa temuan apapun yang dihasilkan pada dasarnya bersifat terbatas pada kasus yang diamati. Oleh karena itu, prinsip berfikir induktif lebih menonjol dalam penarikan kesimpulan dalam penelitian komunikasi kualitatif. Dengan demikian, metode kualitatif menurut (Taylor, Bogdan, \& DeVault, 2015), diharapkan mampu meghasilkan suatu uraian mendalam tentang ucapan, tulisan, dan tingkah laku yang dapat diamati dari suatu individu, kelompok, 
masyarakat, organisasi tertentu dalam suatu konteks setting tertentu yang dikaji dari sudut pandang yang utuh, komprehensif dan holistic. Berdasarkan tataran atau cara menganalisis data, penelitian ini termasuk dalam jenis penelitian deskriptif. Sejalan dengan hal tersebut, (Moleong, 2011) mengemukakan bahwa salah satu karakteristik dalam penelitian kualitatif adalah deskriptif. Dalam hal ini data yang dikumpulkan berupa kata-kata, gambar dan bukan angka-angka. Hal ini disebabkan oleh adanya penerapan metode kualitatif. Selain itu, semua yang dikumpulkan berkemungkinan menjadi kunci terhadap apa yang sudahditeliti. Dengan demikian, laporan penelitian akan berisikutipan-kutipan data untuk memberi gambaran penyajian laporan tersebut lebih menonjol dalam penarikan.

Dalam penelitian ini peneliti menggunakan pendekatan kualitatif dengan teknik pengumpulan data yaitu wawancara dan studi literatur. Wawancara dilakukan terhadap pihak salah satu mahasiswa Universitas Bina Sarana Informatika yang memilik usaha kecil kecilan (Bagas) selaku Wawancara terhadap pihak salah satu mahasiswa Ilmu Komunikasi Universitas Bina Sarana dilakukan untuk mendapatkan gambaran tentang pengguna anedia sosial sebagai alat pemasaran produk UMKM dikalangan Universitas bina Sarana Informatika. Wawancara ini dilakukan dalam rentang waktu April 2021.Selain itu, peneliti juga menggali data melalui studi kepustakaan atau sumber tertulis (library research). Studi kepustakaan dilakukan untuk mendapatkan data-data sekunder dan gambaran konseptual yang mendukung penelitian. Studi kepustakaan juga dilakukan sebagai dasar mengawali penelitian dan penyusunan jurnal.

\section{Hasil dan Pembahasan}

Berdasarkan hasil penelitian selaku Mahasiswa di Univerias Bina Sara Informatika dan perwakilan dari pihak mahasiswa yang memiliki usaha kecil kecilan sebagai berikut:

Salah satu tujuan usaha dengan memanfaatkan sosial media salah satunya adalah untuk menarik minat konsumen baru yang tidak terjangkau, lalu tujuan selanjutnya adalah membentuk circle atau network baru didalam bisnis yang dijalani. saya pernah mempunyai bisnis kecil kecilan dan di pasarkan melalui sosial media, dan Engagement pasarnya cukup lumayan besar. Saya menjalani nya dengan cara grass roots marketing atau strategi pemasaran akar rumput, yang dimana satu orang konsumen dapat menjangkau konsumen yang lebih luas lagi dan mengakar.

Konsumen membeli produk lalu memberikan testimoni nya via instastory di akun pribadi miliknya, konsumen lain akan melihat instastory tersebut dan pada akhirnya membentuk jaringan baru terhadap bisnis yang saya jalani.

Untuk usaha kecil sebaiknya menggunakan platform media sosial Instagram, dikarenakan mempunyai banyak fitur yang mendukung kegiatan UMKM melalui instastory nya, dan juga Instagram dapat menjangkau lebih banyak akun-akun diluar sana, sehingga dapat menarik konsumen baru. Konten yang paling ampuh menarik konsumen untuk akhir ini adalah konten yang berupa audio visual. Tetapi ada hal yang harus diperhatikan, konten audio visual tersebut mengandung sense of humor atau pengetahuan baru untuk masyarakat yang terselip produk yang kita jual, banyak perusahaan besar memakai langkah ini dan hasilnya pun. 
Apakah harus menggunakan media sosial untuk menyediakan layanan pelanggan: Ya harus, misalnya kita membuat e-flyer di instagram feed, Tentunya pelanggan akan mengetahui informasi-informasi produk yang dijual, setelah itu jangan lupa cantumkan nomor telepon atau whatsapp agar pelanggan dapat menindak lanjuti produk yang akan dibeli.

Caranya yang tepat dengan terus melakukan promosi setiap beberapa jam sekali, hal ini harus diperhatikan karena jika kita terlalu sering melakukan promosi, followers yang banyak tersebut malah bisa jadi kabur dan berhenti mengikuti kita. Selain itu buat gebrakan menarik seperti promo di hari-hari besar dan lain sebagainya. Hal itu akan membuat followers tertarik dengan produk yang kita jual.

Alasan mengapa anda lebih menyukai penjualan karena kita dapat mengeksplor followers baru dan networking baru dengan adanya penjualan di media sosial, selain untuk memperlihatkan gaya hidup, media sosial juga mempunyai peran penting untuk mendapatkan pemasukan pribadi tambahan media sosial juga mempunyai peran penting untuk mendapatkan pemasukan pribadi tambahan.

Memaksimalkan pelayanan dan mementingkan kepuasan pelanggan yang no. 1. Dan juga tidak memberatkan pelanggan didalam ongkos kirim.

\section{Kesimpulan}

Teknologi informasi memiliki peranan penting dalam memasarkan produk UMKM di sudah memanfaatkan hal dengan pengenalan produk di situs mereka. Namun, model pemasaran ini baru dilakukan di situs saja. Belum ada optimalisasi pemasaran melalui penggunaan media sosial. Dari sisi mahasiswa, sebagian mahasiswa juga sudah memanfaatkan teknologi informasi untuk memasarkan produk mereka secara mandiri. Namun, keterbatasan kemampuan digital membuat langkah mereka terbatas. Sama seperti pemkab, mereka belum melakukan optimalisasi pemasaran melalui media sosial.

Secara keseluruhan, masyarakat kabupaten Subang mahasiswa Universitas Bina Sarana Informatika yang mempunyai bisnis kecil kecilan belum mengoptimalkan pemasaran produk UMKM melalui media sosial. Ada pun pemasaran melalui media sosial masih dilakukan dalam skala kecil dan belum terorganisir. Pemasaran produk dengan model ini tidak memberi dampak yang signifikan pada penjualan produk. Untuk itu, perlu ada model pemasaran melalui media sosial yang lebih sistematis demi menunjang naiknya jumlah produk yang terjual. 


\section{Bibliografi}

Aisyah, Mimin Nur. (2007). Peran strategi, sumber daya serta perubahan teknologi dan lingkungan terhadap penciptaan keunggulan kompetitif yang berkesinambungan. Jurnal Ekonomi Dan Pendidikan, 4(1).

Brown, Brad, Sikes, Johnson, \& Willmott, Paul. (2013). Bullish on digital: McKinsey global survey results. McKinsey Quarterly, 12, 1-8.

De Fritz, Puti Queenszya. (2020). Penerapan Model Bisnis Berbasis Platform Digital pada PT Kimia Farma (Persero) TBK.

Fajrillah, Fajrillah, Purba, Sukarman, Sirait, Sarida, Sudarso, Andriasan, Sugianto, Sugianto, Sudirman, Acai, Febrianty, Febrianty, Hasibuan, Abdurrozzaq, Julyanthry, Julyanthry, \& Simarmata, Janner. (2020). SMART ENTREPRENEURSHIP: Peluang Bisnis Kreatif \& Inovatif di Era Digital. Yayasan Kita Menulis.

Kriyantono, Rachmat. (2006). Riset komunikasi. Jakarta: Kencana Prenada Media Group.

Moleong, Lexy J. (2011). Metodologi penelitian kualitatif edisi revisi. Bandung: PT Remaja Rosdakarya, 103.

Pawito, Pawito. (2008). Media Massa Dalam Masyarakat Pluralis. Jurnal Ilmu Komunikasi Terakreditasi, 6(2), 72-77.

Sisca, Sisca, Simarmata, Hengki Mangiring Parulian, Grace, Ernest, Purba, Bonaraja, Dewi, Idah Kusuma, Silalahi, Marto, Fajrillah, Fajrillah, Sudarso, Andriasan, \& Sudarmanto, Eko. (2021). Manajemen Inovasi. Yayasan Kita Menulis.

Taylor, Steven J., Bogdan, Robert, \& DeVault, Marjorie. (2015). Introduction to qualitative research methods: A guidebook and resource. John Wiley \& Sons.

Yin, Robert K. (2006). Mixed methods research: Are the methods genuinely integrated or merely parallel. Research in the Schools, 13(1), 41-47. 